\title{
Enquete: Danskhed.cpr
}

Hvad er danskhed? Hvis det flygtige kompleks af både håndgribeligt og uhåndgribeligt materiale, som adskiller danskere fra andre folk, indbefatter dansk identitet - og det gør det selvfølgelig - så må CPR-systemet være en del af det. Alle med bopæl i Danmark er ved lov forpligtet til at have et personnummer, en registreret hovedidentitet, som er nødvendig ved stort set alle formelle henvendelser og gøremål. Disse oplysninger er baseret på Folkeregistret, der blev oprettet 1924, og i 1968 blev alle datasættene centraliseret og elektronificeret i Centralpersonregistret. Det udgør i dag grundlaget for et sammenvævet system af statslige, kommunale og private, mest finansielle, registreringer. CPR-nummeret ledsager alle på en gennemgribende måde i dagligdagen. Som Per Grove, en lokal forretningsmand i Skive, hvor jeg lavede feltarbejde, udtrykker det:

Du bærer det om håndledet, når du bliver født... Du kan aldrig gemme dig .

Det er bagsiden af det... Man er en smule anonym i England..

Hvad end man kan være i Danmark, så er anonymitet og usynlighed ikke nemme valgmuligheder.

Til trods for deres hårdnakkede individualisme og antiautoritære indstilling bekymrer de fleste danskere sig ikke om dette. Selv de, man skulle tro, var imod det, er det ikke. Tag nu Thor, en pjusket, langskægget non-konformist som bor ude på landet og lever af at lave lidt af hvert. En dag, vi sad over en $\varnothing 1$, sagde han:

Nåja, jeg var mod det i starten. Men nu? Du kan jo stadig leve dit eget liv. Du kan stadig leve sammen med andre, det gør egentlig ikke den store forskel. Du kan opgive et falsk CPR-nummer, når det ikke betyder noget!

CPR-systemet springer vitterlig udlændingen i øjnene som noget fremmedartet. Således stod jeg selv der, tidligt i marts 1997, på et af kommunens kontorer i Skive og blev belært af Anette, en af de ansatte. De første seks cifre i alle personnumre, forklarede hun, er personens fødselsdato, de sidste fire er løbenummeret. Anette åbnede CPR-programmet på sin pc'er og brugte som eksempel en fiktiv udlænding, der havde fået opholdstilladelse og derfor skulle have et nummer. Et skærmbillede kom frem, og hun var nu inde på CPR-systemet i København. Da systemet var blevet fodret med fødselsdato og navn, gennemløb det registreret for at se om den pågældende person, eller en med et meget lignende navn, allerede havde et CPR-nummer. Dertil var der rubrikker til køn, indrejsedato, udrejsedato (når det blev relevant), statsborgerskab og nuværende bopæl. Hvis denne liste blev udfyldt, ville computeren tildele et løbenummer, og CPR-nummeret ville være så godt som tatoveret på personens arm. Ved fødsler underretter hospitalet og forældrene det relevante kirkekontor, 
som så sender detaljerne til kommunen. En af de ansatte i kommunen vil så skaffe den nyfødte et CPR-nummer og give forældrene besked. Alle nyfødte skal gennem denne fremgangsmåde. Skulle forældrene undlade at kontakte kirkekontoret, så vil man herfra kontakte forældrene.

Således begynder små danskere deres start i livet. Nogle af dem vil ha-ve fået et CPR-nummer, før de får et navn. Og således kan staten følge sine borgere (og andre). Indbyggerne har pligt til at fortælle kommunen, hvis de skifter adresse eller forlader landet. Hvis de undlader at gøre det, skal man nok finde ud af det. Hvis breve fra det offentlige kommer tilbage til afsenderen, eller hvis postkontoret fortæller kommunen, at breve returneres fra en adresse, spørger man sig lige for hos naboerne. Det kan endda være naboerne, som i første omgang indberetter det.

Hvis folk for ofte lader hånt om denne borgerpligt, kan kommunen give dem bøder. Sædvanligvis gør den det ikke, for det koster mere, end overtræderen ville komme til at betale. Men det var alligevel også Anettes erfaring, at det var usædvanligt, at folk ikke underretter kommunen om deres flytninger:

Af og til har nogen en grund til, at de ikke vil have, at vi skal vide, hvor de bor. En kvinde med to børn for eksempel, hun har måske en ven, som ikke er faderen. Hvis hun nu bor sammen med ham, så får hun ikke det samme i bistandshjælp. Derfor fortæller hun os det ikke. Noget i den retning.

Ikke engang Manden med Leen har den store indvirkning på CPR-systemet: De døde forbliver i registret og beholder deres nummer, om end det bliver inaktivt. Dette er faktisk den store danske genealogi: Blandt de oplysninger, som bliver registreret, er relationer mellem forældre og børn. Anette indtastede sit eget nummer og derpå søgeordet „børn“, og frem på skærmen kom detaljerede oplysninger om hendes søn. Der var dog en ting, Anette ikke kunne fortælle mig, nemlig hvor mange indvandrere, der boede i Skive. Men hun mente dog, at CPR-kontoret i København kunne. Når nogen har fået et CPR-nummer, sagde hun, har de samme status i systemet som alle andre.

Med Anettes egne ord „overvåger CPR-systemet alt, hvad der sker, i en persons liv“: ægteskab, fødsler, skilsmisse og død. Det indeholder dog ikke arbejdsmarkeds-, sundheds- eller kriminalitetsoplysninger, disse informationer befinder sig i særlige databaser registreret under CPR-nummeret, men hvis en persons nuværende adresse er et fængsel, kan man se det i systemet (denne note slettes dog, når vedkommende kommer på fri fod). Skønt systemet ikke registrerer anbringelser på institution som følge af mentale problemer, indeholder det dog oplysninger om den enkeltes sygeforsikring og læge. En særlig kommunal skattedatabase - i Danmark har personskatteinddrivelsen længe være decentraliseret til dette lokale niveau - indeholder nogle af de samme oplysninger.

Forståeligt nok fremhævede Anette systemets sikkerhed. For at få adgang kræves en særlig brugeridentifikation og en hemmelig adgangskode, og systemet overvåger, hvad brugeren foretager sig. Systemet vil ikke 
tillade hende alt, hun kunne for eksempel ikke taste Amalienborg ind og så regne med at se oplysninger om Dronningen. Hun viste mig dog, hvorledes hun kunne indtaste sin brors navn og adresse - han boede et sted på Sjælland - og kalde alle oplysninger frem om ham.

Anette mente ikke, at folk fandt denne mangel på privathed bekymrende. Det var hendes erfaring, at det eneste tidspunkt, systemet virkelig bliver brugt, er når nogen mangler noget eller skal ændre en oplysning. Det er jo alligevel umuligt at få adgang til noget som helst offentligt uden et CPR-nummer, sagde hun. Man har også brug for et CPR-nummer til mange an-dre ting: En bankkonto forudsætter et, og uden en bankkonto er det stort set umuligt at føre en voksentilværelse i Danmark. Da jeg var ved at gå, sagde hun, at det havde været vanskeligt for hende helt at vide, hvad hun skulle fortælle mig, for hun tog det hele fuldstændig for givet. Men hvis jeg skulle få brug for mere information, så vidste jeg, hvor jeg kunne finde hende. Og havde jeg været i besiddelse af et CPR-nummer, så skulle hun nok vide, hvor hun kunne finde mig!

CPR-systemet skaber sin egen folklore og mystik. Nogle var aldeles overbevist om, ja, de vidste det, at det var muligt at identificere indvandrere alene på CPR-nummeret. Man forsikrede mig om, at den måde, tallene blev sammensat på, sikrede, at oplysninger i indvandreres sager blev opbevaret længere i arkiverne end i danskeres. Til trods for sin officielle viden om, at alle CPR-numre havde samme status, syntes selv Anette, at hun havde bemærket, at udlændinge får et højere løbenummer end nyfødte børn.

$\mathrm{Nu}$ har tal selvfølgelig altid haft deres egen magi. Ifølge Thor skulle de sidste fire cifre i CPR-nummeret passe sammen efter en særlig formel. Hvis det første tal er 1, er der kun tre andre bestemte tal, som kan anvendes som de sidste tre i kombinationen. Thor vidste ikke med sikkerhed, hvorfor man skulle have fundet på noget så usandsynligt og upraktisk, men han kan have misforstået, hvordan løbenummeret angiver hvert individs køn og fødselsårhundrede.

Den anden almindelige, folkelige anskuelse om CPR-systemet drejer sig om politiet: „De ved alt... Men de vil ikke fortælle dig, hvad de bruger det til.“ Jeg spurgte en politibetjent om dette. Han vidste ikke, om det ville være muligt at udpege en indvandrer ud fra $\mathrm{CPR}$-nummeret på k $\varnothing$ rekortet, men det var, endnu engang, ligegyldigt. Ud fra CPR-nummeret ville computeren i politibilen kunne fortælle ham om personens nationalitet, kriminelle karriere, enhver bopæl livet igennem, historie som bilejer, detaljer om førerbevis og jagttegn samt enhver nuværende position i de væbnede styrker.

Som den lokale vicepolitiinspektør fortalte mig: „Vi kan anvende alle systemer“". Da jeg spurgte, hvilken slags oplysninger, de kunne få frem fra disse systemer, lød hans ligefremme svar: „Faktisk alt“ - adresse, alder, strafferegister, kørekort, ægteskabelig status og detaljerede oplysninger om personens børn. Det er let at identificere indvandrere, fordi systemet oplyser om fødested og om, hvorvidt personen er dansk statsborger. Havde 
systemet indvirkninger på de civile frihedsrettigheder? „Der har da været nogen diskussion om registret i samfundet,“ sagde han, ,,men der har ikke været stor uenighed. Fra politiets synspunkt er der ganske enkelt tale om forøget effektivitet.“

Og er der noget danskere sætter pris på, så er det effektivitet. Den er lige så meget en del af Danmark og danskhed som konsensus, hygge, skål!, janteloven, Tivoli (eller Legoland) og Dannebrog. Faktisk lige så meget en del af danskheden som CPR-systemet.

Richard Jenkins, professor Department of Sociological Studies University of Sheffield, UK

Oversat af Kennet Pedersen 